\title{
Miðmætisspeglanir á Íslandi: Árangur og ábendingar
}

\section{Póra Sif Ólafsdóttir ${ }^{1}$ deildarlæknir á skurðdeild}

\section{Gunnar}

Guðmundsson ${ }^{2,4}$ lungnalæknir

Jóhannes Björnsson ${ }^{3,4}$ meinafræðingur

Tómas

Guðobjartsson ${ }^{1,4}$

brjóstholsskurðlæknir

Lykilorð: miðmætisspeglun, lungnakrabbamein, stigun, sarklíki, fylgikvillar, árangur, blæðing, skurðdauði.

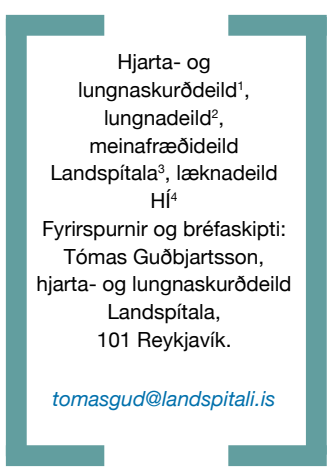

\section{Ágrip}

Inngangur: Pegar nálgast parf sýni úr miðmæti, til dæmis við stigun lungnakrabbameins eða við greiningu æxla af ópekktum uppruna, er miðmætisspeglun (mediastinoscopy) kjörrannsókn. Ekki liggja fyrir upplýsingar um ábendingar eða árangur pessara aðgerða hér á landi og er markmið rannsóknarinnar að bæta úr pví.

Efniviður og aðferðir: Afturskyggn rannsókn á öllum sjúklingum sem gengust undir miðmætisspeglun á Íslandi 1983-2007. Listi yfir sjúklinga fékkst úr aðgerða- og meinafræðiskrá Landspítala og klínískar upplýsingar úr sjúkraskrám. Borin voru saman fimm ára tímabil.

Niðurstöður: Alls voru gerðar 278 aðgerðir á tímabilinu en upplýsingar vantaði hjá 17 sjúklingum og var peim sleppt. Eftir í rannsókninni voru 261 sjúklingur (159 karlar, 102 konur, meðalaldur 59 ár). Aðgerðum fjölgaði úr 16 á fyrsta tímabili í 85 á pví síðasta $(\mathrm{p}<0,01)$. Helstu ábendingar voru stigun lungnakrabbameins $(61,3$ $\%$ ), ópekkt fyrirferð í miðmæti (24,5\%) og grunur um sarklíki (8,8\%). Ábendingar héldust óbreyttar á milli tímabila. Miðgildi aðgerðartíma var 30 mínútur (bil 10-320) og legutíma 1 dagur (bil 1-26). Algengustu vefjagreiningar voru ósérhæfðar breytingar $(33,6 \%)$, meinvörp lungnakrabbameins $(23,8 \%)$ og sarklíki $(12,7 \%)$. Helstu fylgikvillar voru hæsi vegna raddbandalömunar $(1,5 \%)$, blæðing (>500 ml) (1,1\%), og skurðsýking $(0,3 \%)$. Tvö dauðsföll urðu innan 30 daga $(0,76 \%)$; eitt vegna blæðingar.

Ályktun: Miðmætisspeglunum fer fjölgandi á Íslandi, sérstaklega í tengslum við stigun lungnakrabbameins. Um er að ræða örugga rannsókn par sem tíðni fylgikvilla er lág og sértæk niðurstaða fæst í flestum tilvikum.

\section{Inngangur}

Miðmætisspeglun hefur í fimm áratugi verið notuð til greiningar sjúkdóma í miðmæti. Eric Carlens háls-, nef og eyrnalæknir í Svípjóð framkvæmdi fyrstu miðmætisspeglunina árið
$1959^{1}$ og hefur hún síðan verið talin kjörrannsókn við sýnatöku úr miðmæti. 2, 3 Gerður er 2-3 cm skurður neðarlega á hálsi og röri með ljósgjafa rennt niður eftir framhlið barkans. Komist er niður fyrir barkakjöl (carina) og sýni tekin úr eitlum eða fyrirferðum í fremra miðmæti, séu pær til staðar. Miðmætisspeglun má einnig framkvæma með aðstoð holsjár sem tengd er við sjónvarpsskjá (video-assisted mediastinoscopy). ${ }^{4}$

Miðmætisspeglun hefur sannað gildi sitt við uppvinnslu ýmissa sjúkdóma, sérstaklega við stigun lungnakrabbameins og hjá sjúklingum með stækkaða miðmætiseitla, til dæmis pegar grunur leikur á eitilkrabbameini eða sarklíki." ${ }^{6}$ Rannsóknin er tiltölulega fljótleg og legutími yfirleitt stuttur. Engu að síður getur hún verið tæknilega flókin og fylgikvillar hættulegir, ekki síst blæðingar sem getur verið erfitt að stöðva. 2, 7,8

Árangur miðmætisspeglana hér á landi hefur ekki verið rannsakaður áður og var tilgangur rannsóknarinnar að bæta úr pví. Aðaláhersla var lögð á ábendingar aðgerðarinnar og alvarlega fylgikvilla en einnig að meta hversu oft fékkst sértæk vefjagreining og kanna afdrif sjúklinganna.

\section{Efniviður og að̆ferð̈ir}

Rannsóknin er afturskyggn og nær til allra sjúklinga sem gengust undir miðmætisspeglun á Íslandi á 25 ára tímabili, eða frá 1. janúar 1983 til 31. desember 2007. Sjúklingar voru fundnir með leit í aðgerðaskrám Landspítala. Alls fundust 278 tilfelli í pessum skrám en hjá 17 sjúklingum fundust sjúkraskrár ekki $(6,1 \%)$ og var peim tilfellum sleppt.

Klínískar upplýsingar voru fengnar úr sjúkraskrám, aðgerðarlýsingum og vefjasvörum. Skráðar voru 53 breytur í tölvuforritið Excel, par á meðal aldur við greiningu, kyn, áhættupættir aðgerðar, aðgerðardagur, legutími og fylgikvillar í og eftir aðgerð. Meiriháttar blæðing var skilgreind sem blæðing yfir $500 \mathrm{ml}$. Ef sjúklingur lést innan 30 daga frá aðgerð var pað skilgreint sem 
Mynd 1. Helstu eitlastöðvar í miðmæti. Við miðmætisspeglun er hægt að ná til efstu stöđvanna, 2 3, 4 og 7. Byggt á Naruke og lítillega breytt. ${ }^{9}$ Myndin hefur ádur birst i heimild og er birt með leyfi útgefenda.

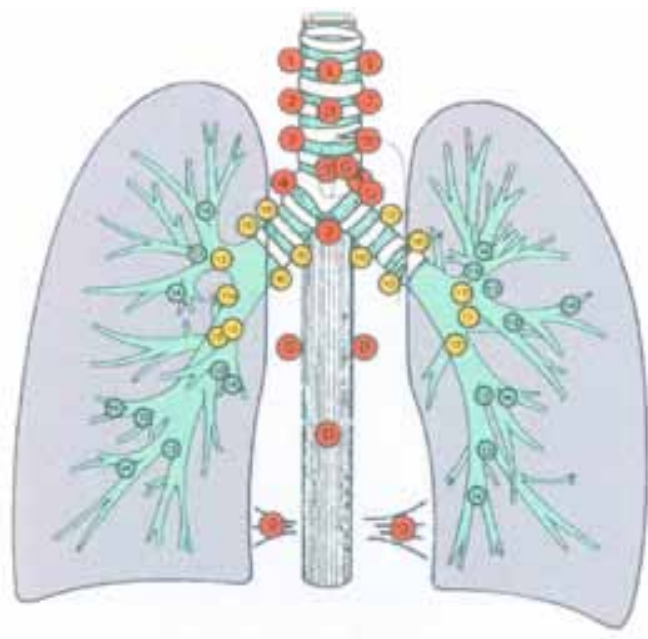

skurðdauði (operative mortality). Einnig var kannað hversu margir sjúklingar létust í sömu legu (hospital mortality).

Vefjasýni voru skoðuð í vafatilfellum en annars stuðst við vefjasvör. Eitlastöðvar voru flokkaðar samkvæmt flokkun Mountain og Dresler (sjá mynd 1$).{ }^{9}$

Við tölfræðiúrvinnslu var notast við tölvuforritið Excel og kí-kvaðrat og t-próf notuð við samanburð á hópum. Öll tilskilin leyfi lágu fyrir áđur en rannsóknin hófst, meðal annars frá Persónuvernd, Siðanefnd Landspítala og frá framkvæmdastjóra lækninga á Landspítala.

\section{Niðurstöður}

Af 261 aðgerð voru 159 framkvæmdar á körlum (60,9\%). Meðalaldur fyrir bæði kyn var 59 ár (bil 11-89 ár) (tafla I). Aðgerðum fór fjölgandi eftir pví sem leið á tímabilið, eða úr 16 aðgerðum á árunum 1983-1987 í 85 aðgerðir 2003-2007 (p<0,01).

Aðgerðirnar voru framkvæmdar af sjö skurðlæknum sem framkvæmdu á bilinu 6-83 aðgerðir hver (miðgildi 27,5 aðgerðir). Hjá 24 sjúklingum

Tafla I. Yfirlit yfir sjúklinga og algengustu fylgikvilla eftir 261 miðmætisspeglun á Íslandi 1983-2007. Sjúklingar geta haft fleiri en einn fylgikvilla. Gefinn er upp fjöldi og \% í sviga.

\begin{tabular}{lc}
\hline Fjöldi sjúklinga & 261 \\
\hline Karlar & $159(60,9)$ \\
\hline Meðalaldur, ár (bil) & $59(11-89)$ \\
\hline Fylgikvilli & Fjöldi $(\%, \mathrm{n} / 261)$ \\
\hline Hæsi & $4(1,5)$ \\
\hline Loftbrjóst & $1(0,3)$ \\
\hline Sýking & $1(0,3)$ \\
\hline Blæðing & $3(1,1)$ \\
\hline Tíðni fylgikvilla & $7(2,7)$ \\
\hline Dauði $<30$ daga & $2(0,76)$ \\
\hline
\end{tabular}

(9,2\%) var rannsóknin framkvæmd með aðstoð holsjár sem tengd var við sjónvarp. Sýni voru tekin með töngum og minni blæðingar stöðvaðar með rafhníf og sellúlósa-grisjum (Surgicel ${ }^{\circledR}$ ). Sjúklingar voru yfirleitt svæfðir með hefðbundinni berkjurennu en eftir 2005 var í 14 tilfellum komið fyrir tvíopa berkjurennu í upphafi svæfingar og miðmætisspeglun framkvæmd í sömu svæfingu og brottnám blaðs eða lunga.

Mynd 2 sýnir ábendingar aðgerðanna eftir tímabilum. Stigun lungnakrabbameins reyndist algengasta ábendingin á öllum tímabilum, eða í 61,3\% tilfella, en pará eftir kom uppvinnsla á fyrirferð í miðmæti (24,5\%). Aðrar ábendingar voru sjaldgæfari.

Miðgildi aðgerðartíma var 30 mínútur (bil 10320) og miðgildi legutíma einn sólarhringur. Alls útskrifuðust 7,3\% sjúklinga samdægurs og 49,1\% til viðbótar innan sólarhrings.

Í 17 aðgerðanna (6,5\%) voru engin sýni tekin, oftast vegna pess að eitlar fundust ekki eða að ekkert óeðlilegt sást við speglunina. Á myndum 3 og 4 er sýnd skipting fyrir bæði góð- og illkynja vefjagreiningar hjá peim 244 sjúklingum par sem vefjasýni lá fyrir. Meðal illkynja greininga voru lungnakrabbamein önnur en smáfrumukrabbamein (ÖES) algengust (23,8\%) en par á eftir meinvörp frá öðrum krabbameinum $(9,0 \%)$, smáfrumukrabbamein $(4,1 \%)$ og eitilkrabbamein $(2,9 \%)$. Pegar ekki var um illkynja sjúkdóma að ræða voru ósérhæfðar breytingar algengasta greiningin $(33,6 \%)$, og sarklíki greindist hjá 12,7\% sjúklinga. Eðlilegir eitlar sáust hjá 7,8\% sjúklinga en 6,1\% höfðu aðra góðkynja sjúkdóma eins og til dæmis berkla, æxli í hóstarkirtli og Castleman’s sjúkdóm.

Sýni voru oftast tekin frá eitlastöð 4 hægra megin eða í 46,7\% tilvika, par á eftir frá eitlastöð 4L (20,9\%) og eitlastöð $3(16,4 \%)$ (mynd 1). Hjá 95 sjúklingum vantaði upplýsingar um hvaðan eitilsýni var tekið og í 17 tilvika voru engin sýni tekin (sjá áður). Meðalfjöldi eitlastöðva sem tekin voru sýni frá í hverri aðgerð var 1,7 (bil 1-4). Pegar stigunaraðgerðir vegna lungnakrabbameins voru skoðaðar sérstaklega voru að meðaltali tekin sýni frá 1,8 eitlastöð, eða frá 1,4 eitlastöð á tímabilinu 1998-2002 samanborið við 2,2 eitlastöðvar tímabilið 2003-2007 (p<0,01).

Alls greindust sjö sjúklingar af 261 með fylgikvilla $(2,7 \%)$ og tveir sjúklingar létust innan 30 daga frá aðgerð (0,76\%). Í töflu I eru sýndir algengustu fylgikvillarnir. Algengust var vinstri raddbandalömun (1,5\%), næst á eftir blæðingar (1,1\%), síðan loftbrjóst og lungnabólga.

Af fjórum sjúklingum með hæsi lagaðist einn innan átta mánaða og annar varð betri eftir innspýtingu teflons í raddband. Fyrir hina tvo 
sjúklingana vantaði upplýsingar um afdrif raddbandalömunar. Loftbrjóst greindist eftir aðgerð í einu tilviki og fékk sá sjúklingur brjóstholskera í sólarhring. Annar sjúklingur, 71 árs karlmaður með lungnakrabbamein, fékk alvarlega Pseudomonas lungnabólgu eftir aðgerð og lést 11 dögum síðar. Krufning sýndi að lungnakrabbamein hafði dreift sér í miðmætiseitla (stig IIIB).

Hjá premur sjúklingum urðu meiriháttar blæðingar (>500ml) í aðgerð (1,1\%). Í tveimur tilvikum blæddi frá bláæð og náðist að stöðva blæðinguna með sellulósagrisjum og tuskum sem skildar voru eftir í sárinu. Priðja tilfellið var 46 ára gömul kona með sögu um berkla og nýgreinda fyrirferð í miðmæti. Hún reyndist vera með lungnakrabbamein og við sýnatöku frá stórri fyrirferð framan við barkakjöl rofnaði æxlið sem óx inn í efri holæð og ósæð. Gerður var bráða brjóstholsskurður og sjúklingur tengdur við hjarta og lungnavél. Ekki náðist stjórn á blæðingunni og sjúklingurinn lést á skurðarborðinu eftir fimm klukkutíma aðgerð.

\section{Umræơur}

Pessi rannsókn sýnir að árangur miðmætisspeglana er góður hér á landi, en fylgikvillar eru fátíðir (2,7\%) og dánarhlutfall aðeins 0,8\%. Niðurstöður okkar eru í samræmi við fjölda erlendra rannsókna par sem tíðni fylgikvilla er yfirleitt á bilinu 0,6-2,7\% og skurðdauði frá 0 og upp í 0,3\% (tafla II). Sérhæfð vefjagreining náðist î langflestum tilvikum eða hjá 68,6\% sjúklinga.

Blæðingar eru langalgengasti fylgikvillinn og geta verið lífshættulegar.7, 8 Oftast er um vægar blæðingar að ræða og blæðingin stöðvast yfirleitt með rafhníf (diathermi) eða uppleysanlegum sellulósagrisjum (Surgicel ${ }^{\circledR}$ ). Blæðing getur pó orðið veruleg, til dæmis ef óvart er tekið sýni úr lungnaslagæð eða efri holæð. Í slíkum tilvikum er miðmætið pakkað með grisjum, en ef pað dugar ekki getur purft að opna brjóstholið. Aðeins purfti að opna brjóstholið einu sinni í 261 aðgerð (0,4\%) sem telst lágt hlutfall. ${ }^{7}$ Tíðni alvarlegra blæðinga (>500 ml) reyndist $1,1 \%$ sem er sambærilegt við aðrar stórar rannsóknir. ${ }^{7,8}$ Í pessu sambandi er rétt að hafa í huga að okkar skilgreining á alvarlegri blæðingu var rýmri en í sumum rannsóknanna í töflu II. Til dæmis miðaðist skilgreining Park og félaga við blæðingu sem purfti að stöðva með opinni skurðaðgerð og tíðni alvarlegra blæðinga í peirri rannsókn var pví aðeins $0,4 \% .{ }^{7}$ Annar pekktur alvarlegur fylgikvilli pessara aðgerða er lömun á vinstri raddbandataug (n. laryngeus recurrens sin.) sem lýsir sér með hæsi. ${ }^{10}$ Taugin liggur rétt við eitlastöð $4 \mathrm{~L}$ og getur orðið fyrir áverka pegar
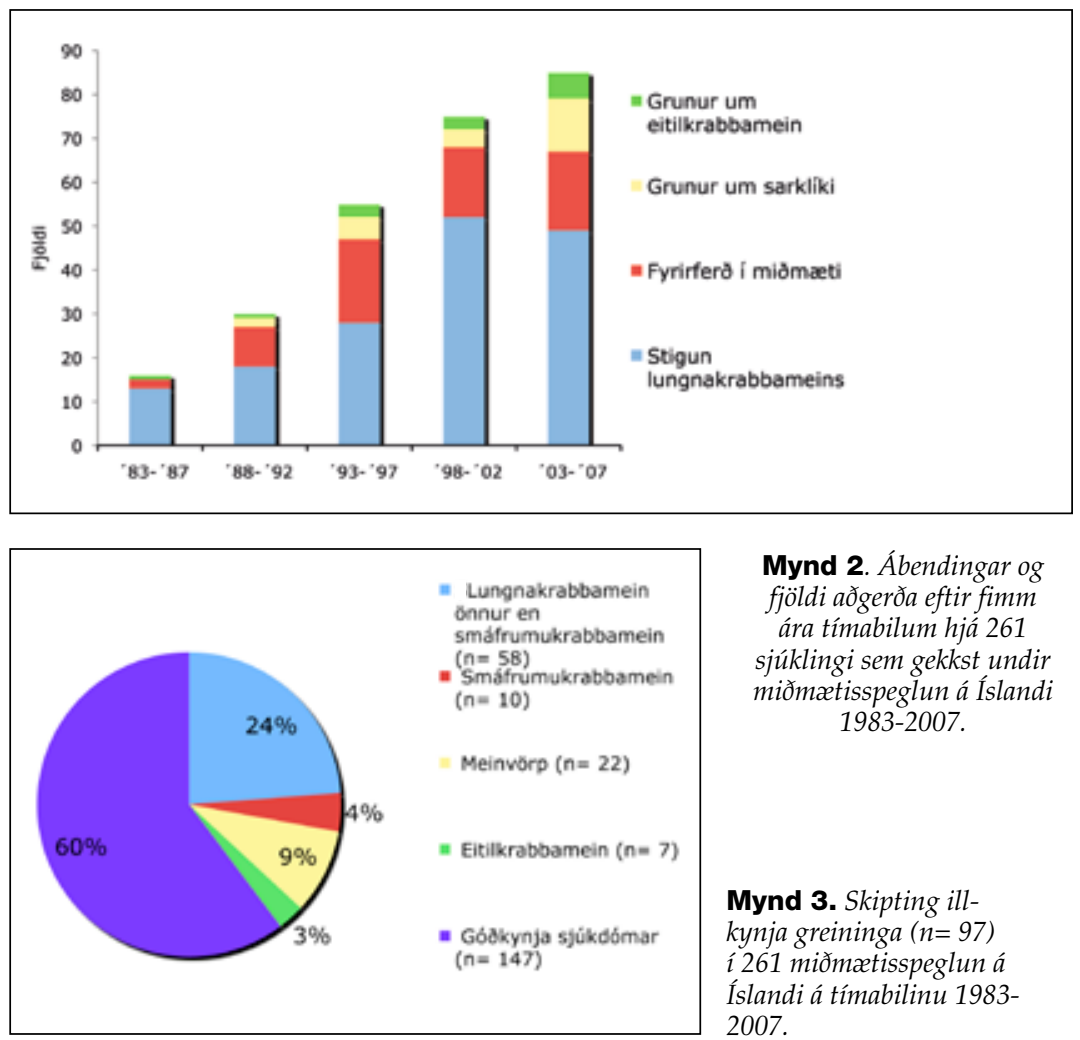

Mynd 2. Ábendingar og fjöldi aðgerða eftir fimm ára tímabilum hjá 261 sjúklingi sem gekkst undir miðmætisspeglun á Íslandi 1983-2007.

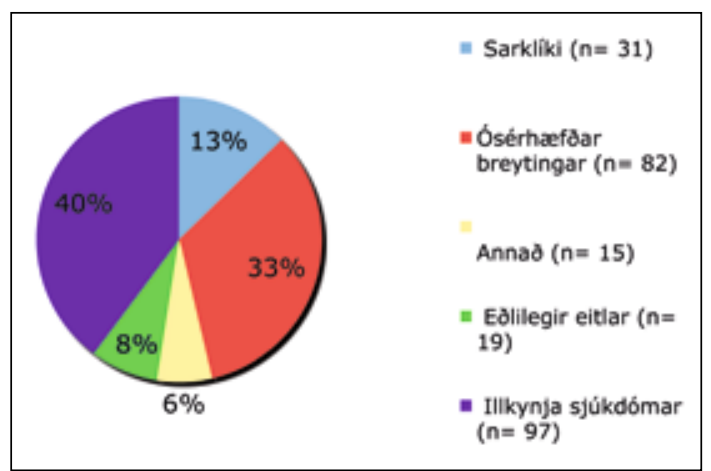

Mynd 3. Skipting ill-

kynja greininga $(n=97)$ í261 miðmætisspeglun á Íslandi á tímabilinu 19832007.

tekið er sýni úr pessari stöð. Oft gengur lömun til baka en við varanlegan skaða getur purft að grípa til pess að sprauta teflon í raddböndin eða jafnvel gera skurðaðgerð á peim. ${ }^{11}$

Eins og sést vel á mynd 2 hefur aðgerðunum fjölgað stöðugt á tímabilinu. Munar par mestu um aukningu í stigun lungnakrabbameins. Pessi
Mynd 4. Skipting góðkynja greininga (n=147) i 261 miðmætisspeglun á Íslandi á tímabilinu 1983-2007.
Tafla II. Samanburður helstu rannsókna á árangri miðmætisspeglana, meðal annars tíðni fylgikvilla og skurðdauða (<30 daga).

\begin{tabular}{lccc}
\hline Höfundur (ár) & Fjöldi sjúklinga & Fylgikvillar (\%) & Skurðdauði (\%) \\
\hline Luke $(1986)^{22}$ & 1000 & 2,3 & 0 \\
\hline Puhakka (1987) & 2021 & 2,3 & 0 \\
\hline Cybulshky $(1994)^{21}$ & 1015 & 1,4 & 0 \\
\hline Hammoud $\left(1999{ }^{2}\right.$ & 2137 & 0,6 & 0,2 \\
\hline Urschel (2000) & 324 & - & 0,3 \\
\hline Lemaire $(2006)^{8}$ & 2145 & 1,1 & 0,05 \\
\hline Ólafsdóttir (2009) & 261 & 2,7 & 0,8 \\
\hline
\end{tabular}


próun er í samræmi við erlendar rannsóknir par sem stigun og greining lungnakrabbameins er algengasta ábendingin fyrir miðmætisspeglun og par á eftir sýnatökur vegna eitlastækkana eða ópekktra fyrirferða í miðmæti. ${ }^{2}$

Nákvæm stigun miðmætiseitla er afar mikilvæg í uppvinnslu og meðferð sjúklinga með lungnakrabbamein. ${ }^{3}$ Niðurstöður úr miðmætisspeglun geta til dæmis ráðið úrslitum um hvort skurðaðgerð komi til greina (útiloka stig IIIB) eða hvort beita purfi viðbótarmeðferð fyrir hugsanlega skurðaðgerð (stig IIIA). ${ }^{3}$ Næmi rannsóknarinnar er mjög hátt, eða allt að 90\% og sértæki 100\%.3,15,16 Á síðustu árum hafa nýjar rannsóknaraðferðir rutt sér til rúms erlendis, sérstaklega jáeindaskanni, en næmi hans við greiningu lungnakrabbameins er á bilinu $79-85 \%$ og sértæki 89-92\%. ${ }^{12}$ Jákvæð skönn verður pó að staðfesta með vefjasýni og oftast fást pau með miðmætisspeglun. Einnig er hægt að ná sýni úr miðmætiseitlum með ástungu í gegnum berkju (transbronchial needle aspiration TBNA) eða vélinda (esophageal ultrasound EUS). ${ }^{13}$ Er pá notast við ómhaus tengdan speglunartæki til að staðsetja stækkaða eitla og síðan stinga á peim. Pessar aðferðir eru ekki eins næmar (79-92\%) ${ }^{13}$, ${ }^{14}$ og miðmætisspeglun. Pær koma pó til greina 1 völdum tilfellum, sérstaklega við sýnatöku eitla neðarlega í miðmæti, en pangað er ekki hægt að komast með miðmætisspeglun. ${ }^{15}$

Jáeindaskanni er ekki í boði hér á landi og miðmætisspeglun pví mikilvæg við uppvinnslu sjúklinga með lungnakrabbamein. Ef fylgt er erlendum leiðbeiningum er mælt með pví að framkvæma miðmætisspeglun hjá porra sjúklinga (hugsanlega má sleppa sjúklingum með T1 æxli, $<3 \mathrm{~cm}$ ) með lungnakrabbamein og ná sýnum úr eitlum í fremra miðmæti. Petta á einnig við pótt eitlar virðist eðlilega stórir á tölvusneiðmyndum. ${ }^{3,16}$ Ástæðan er sú að í allt að 15-20\% tilvika geta leynst smásæ meinvörp í eðlilega stórum eitlum hjá sjúklingum með lungnakrabbamein af ekki-smáfrumugerð. ${ }^{16}$ Athygli vekur að í stigunaraðgerðum hér á landi voru aðeins tekin sýni frá tæplega tveimur eitilstöðvum, en sýnum fjölgaði pó á síðari hluta tímabilsins. Petta er mikilvægt, enda er mælt með pví að taka sýni frá að minnsta kosti fimm mismunandi stöðvum í slíkum speglunum. $^{3}$

Hjá hluta sjúklinganna er miðmætisspeglun gerð vegna gruns um góðkynja sjúkdóma. Pannig reyndist 31 sjúklingur (12\%) hafa sarklíki. Í rannsókn á sarklíki á Íslandi frá 1981 til 2003 voru 60 af 235 sjúklingum (25,5\%) greindir með miðmætisspeglun sem var önnur algengasta greiningaraðferðin á eftir berkjuspeglun. ${ }^{17}$ Í okkar rannsókn voru ósérhæfðar breytingar algengastar af góðkynja orsökum, eða í 33,6\% tilfella. Petta er svipað og 1 erlendum rannsóknum. ${ }^{2}$

Styrkur pessarar rannsóknar er að hún nær yfir langt tímabil en auk pess er um tilfelli frá einni stofnun að ræða sem aðeins sjö skurðlæknar hafa framkvæmt. Hins vegar er veikleiki að rannsóknin er afturskyggn, sérstaklega hvað viðkemur skráningu fylgikvilla, en par var stuðst við upplýsingar úr sjúkraskrám.

Miðmætisspeglunum fjölgar hér á landi, aðallega í tengslum við stigun sjúklinga með lungnakrabbamein. Ræður par miklu að ábendingar fyrir miðmætisspeglun eru orðnar skýrari. Einnig sýnir rannsóknin að miðmætisspeglun er fljótleg rannsókn og örugg og tíðni alvarlegra fylgikvilla lág.

\section{Pakkir}

Fær Gunnhildur Jóhannesdóttir fyrir aðstoð við leit að sjúklingagögnum. Pessi rannsókn var styrkt af Minningarsjóði Bergpóru Magnúsdóttur og Jakobs J. Bjarnasonar og Vísindasjóði Landspítala.

\section{Heimildir}

1. Carlens E. Mediastinoscopy: a method for inspection and tissue biopsy in the superior mediastinum. Dis Ches 1959; 36: 343-52.

2. Hammoud ZT, Anderson RC, Meyers BF, et al. The current role of mediastinoscopy in the evaluation of thoracic disease. J Thorac Cardiovasc Surg 1999; 118: 894-9.

3. Detterbeck FC, Jantz MA, Wallace M, Vansteenkiste J, Silvestri GA. Invasive mediastinal staging of lung cancer: ACCP evidence-based clinical practice guidelines (2nd edition). Chest 2007;132(3 Suppl):202S-220S

4. Venissac N, Alifano M, Mouroux J. Video-assisted mediastinoscopy: experience from 240 consecutive cases. Ann Thorac Surg 2003; 76: 208-12.

5. Iannuzzi MC, Rybicki BA, Teirstein AS. Sarcoidosis. N Engl J Med 2007; 357: 2153-65

6. Sandlund JT, Downing JR, Crist WM. Non-Hodgkin's lymphoma in childhood. N Engl J Med 1996; 334: 1238-48.

7. Park BJ, Flores R, Downey RJ, Bains MS, Rusch VW Management of major hemorrhage during mediastinoscopy. J Thorac Cardiovasc Surg 2003; 126: 726-31.

8. Lemaire A, Nikolic I, Petersen T, et al. Nine-year single center experience with cervical mediastinoscopy: complications and false negative rate. Ann Thorac Surg 2006; 82: 1185-9; discussion 1189-90.

9. Naruke T, Goya T, Tsuchiya R, Suemasu K. Prognosis and survival in resected lung carcinoma based on the new international staging system. J Thorac Cardiovasc Surg 1988; 96: 440-7.

10. Widstrom A. Palsy of the recurrent nerve following mediastinoscopy. Chest 1975; 67: 365-6.

11. Kwon TK, Buckmire R. Injection laryngoplasty for management of unilateral vocal fold paralysis. Curr Opin Otolaryngol Head Neck Surg 2004; 12: 538-42.

12. Devaraj A, Cook GJ, Hansell DM. PET/CT in non-small cell lung cancer staging-promises and problems. Clin Radiol 2007; 62: 97-108.

13. Annema JT, Versteegh MI, Veselic M, Voigt P, Rabe KF. Endoscopic ultrasound-guided fine-needle aspiration in the diagnosis and staging of lung cancer and its impact on surgical staging. J Clin Oncol 2005; 23: 8357-61.

14. Toloza EM, Harpole L, McCrory DC. Noninvasive staging of non-small cell lung cancer: a review of the current evidence. Chest Jan 2003; 123(1 Suppl):137S-146S.

15. Whitson BA, Groth SS, Maddaus MA. Surgical assessment and intraoperative management of mediastinal lymph nodes in non-small cell lung cancer. Ann Thorac Surg 2007; 84: 1059-65. 
16. De Leyn P, Lardinois D, Van Schil PE, et al. ESTS guidelines for preoperative lymph node staging for non-small cell lung cancer. Eur J Cardiothorac Surg 2007; 32: 1-8.

17. Haraldsdóttir SÓ, Jörundsdóttir KB, Yngvason F, Björnsson J, Gíslason P. Sarklíki á Íslandi 1981-2003. Læknablaðið 2007; 93: 105-9.

18. Harðardóttir H, Hannesson P, Guðbjartsson T. Stigun. Í: Lungnakrabbamein, ritstj. Guðbjartsson T, Jónsson S. Ísland 2009.

19. Puhakka HJ. Complications of mediastinoscopy. J Laryngol Otol 1989; 103: 312-5.
20. Urschel JD. Conservative management (packing) of hemorrhage complicating mediastinoscopy. Ann Thorac Cardiovasc Surg 2000; 6: 9-12.

21. Cybulsky IJ, Bennett WF. Mediastinoscopy as a routine outpatient procedure. Ann Thorac Surg 1994; 58: 176-8.

22. Luke WP, Pearson FG, Todd TR, Patterson GA, Cooper JD. Prospective evaluation of mediastinoscopy for assessment of carcinoma of the lung. J Thorac Cardiovasc Surg 1986; 91: 53-6.

\section{Mediastinoscopy in Iceland: Indications and surgical outcome}

Introduction: Mediastinoscopy is an important tool for staging lung cancer and evaluating mediastinal pathology. The objective of this retrospective study was to investigate the indications and safety of mediastinoscopy in a well defined cohort of patients.

Material and methods: All patients that underwent mediastinoscopy in Iceland between 1983-2007 were included. Clinical information was obtained from patient charts and pathology reports rewied. The study-period was divided into 5-year periods for comparison,

Results: Altogether 278 operations were performed but in 17 cases data was missing, leaving 261 patients for analysis (mean age $59 \mathrm{yrs}$, range 11-89, 159 males). A steady increase was seen in the number of operations, or from 16 to 85 during the first and last periods, respectively $(p<0.01)$. Staging of lung cancer $(61,3 \%)$, evaluation of mediastinal tumors $(24,5 \%)$, and suspected sarcoidosis $(8,8 \%)$ were the most common indications. Mean operating time was 30 minutes (range 10-320) and median hospital stay 1 day (range 0,5-26). The most common histological diagnosis were nonspecific changes (33,6\%), lung cancer $(23,8 \%)$ and sarcoidosis $(12,7 \%)$. Seven patients $(2.7 \%)$ had complications; including $4(1.5 \%)$ with hoarsness due to left recurrent nerve injury, one $(0,3 \%)$ with pneumothorax and two with $>500 \mathrm{ml}$ hemorrhage $(1.1 \%)$. There were two operative deaths ( $<30$ days), one due to major intraoperative bleeding.

Conclusions: The number of mediastinoscopies is increasing in Iceland, especially as a part of lung cancer staging. Mediastinoscopy is a safe procedure with low mortality and morbidity, where a specific diagnosis is obtained in most cases.

Olafsdottir TS, Gudmundsson G, Bjornsson J, Gudbjartsson

Mediastinoscopy in Iceland: Indications and surgical outcome. Icel Med J 2010; 96: 399-403.

Key words: Mediastinoscopy, lung cancer, staging, sarcoidosis, complications, surgical outcome, bleeding, operative mortality.

Correspondence: Tómas Guðbjartsson, tomasgud@landspitali.is 